\title{
Microstructure of the Transitional Area of the Connection of a High-temperature Ni-based Brazing Alloy and Stainless Steel AISI 321 (X6CrNiTi 18-10)
}

\author{
R. Augustin, R. Koleňák
}

\begin{abstract}
This paper presents a detailed examination of the structure of the transitional area between a brazing alloy and the parent material, the dimensions of the diffusion zones that are created, and the influence on them of a change in the brazing parameters. Connections between Ni-based brazing alloys (NI 102) with a small content of B and AISI 321 stainless steel (X6CrNiTi 18-10) were created in a vacuum $\left(10^{-2} \mathrm{~Pa}\right)$ at various brazing temperatures and for various holding times at the brazing temperature. Various specimens were tested. First, the brazing alloys were wetted and the dependence of the wetting on the brazing parameters was assessed. Then a chemical microanalysis was made of the interface between the brazing alloy and the parent material. The individual diffusion zones were identified on pictures from a light microscope and REM, and their dimensions, together with their dependence on the brazing parameters, were determined.
\end{abstract}

Keywords: NI 102 brazing alloy, AISI 321, wetting, chemical microanalysis, diffusion zones.

\section{Introduction}

High-temperature brazing of stainless steels is a specific method for connecting materials that can create high-quality, demountable connections without local thermal impact on the connected material. Hightemperature brazing can be applied where it is not desirable to use welding because of the thermal impact or because of the complexity of the connections that will be created [1].

Nickel-based brazing alloys are the most suitable for high-temperature brazing of stainless steel. When parts made of stainless steel are connected by a hightemperature nickel brazing alloy, the metallurgical connection has characteristics similar to those of a welded connection. However, in contrast to welding there is no melting of the parent material (PM) due to the significantly lower melting point of the brazing alloys [2].

A high-vacuum atmosphere in high-temperature brazing prevents the brazing alloy and PM interacting with the ambient atmosphere, so it is not necessary to use fluxes with this method. At the same time, the vacuum atmosphere has no effect on the physical characteristics of PM. Brazing in a vacuum complies with the latest world trends in machine technology, and is therefore also the most favoured high-temperature brazing method [3].

High-temperature brazing of stainless steels with nickel-based brazing alloys in a vacuum has already been used for a long time in practical applications. It is therefore desirable to know the influence of the basic brazing parameters on the characteristics of the brazing alloy and the connection that is formed. It is then possible to optimize the initial parameters in such a way that the connections meet the requirements made on them [4].

\section{Materials and methods}

Austenitic stainless steel AISI 321 (X6CrNiTi 18-10, DIN 1.4541) was selected for the purposes of the experiment. High alloyed austenitic steels cannot be refined, so they can also be brazed with slow cooling. The exact chemical composition of the 17246 steel is shown in table 1 [5].

Two brazing alloys of similar chemical composition containing B were selected from the series of high-temperature nickel-based brazing alloys, see Tab. 2. According to the STN EN 1044 standard, they both fall under code NI 102.

Table 1: Chemical composition of AISI 321

\begin{tabular}{|c|c|c|c|c|c|c|c|c|}
\hline $\mathrm{Fe}$ & $\mathrm{Cr}$ & $\mathrm{Ni}$ & $\mathrm{Mn}$ & $\mathrm{Si}$ & $\mathrm{C}$ & $\mathrm{W}$ & $\mathrm{Ti}$ & $\mathrm{Mo}$ \\
\hline $67.00 \%$ & $19.30 \%$ & $8.12 \%$ & $1.27 \%$ & $0.41 \%$ & $0.02 \%$ & $0.63 \%$ & $0.36 \%$ & $0.06 \%$ \\
\hline
\end{tabular}


Table 2: Chemical composition of brazing alloy NI 102

\begin{tabular}{|l|c|c|c|c|c|c|}
\hline Brazing alloy & $\mathrm{Ni}$ & $\mathrm{Cr}$ & $\mathrm{Si}$ & $\mathrm{B}$ & $\mathrm{C}$ & $\mathrm{Fe}$ \\
\hline NI 102-01 & $83.5 \%$ & $6.5 \%$ & $4.5 \%$ & $3.0 \%$ & $0.05 \%$ & $4.0 \%$ \\
\hline NI 102-02 & $82.0 \%$ & $7.0 \%$ & $4.0 \%$ & $2.0 \%$ & $0.15 \%$ & $4.5 \%$ \\
\hline
\end{tabular}

The brazing parameters shown in Tab. 3 were selected with reference to the objective of the paper, in order to be able to assess the influence of specific variables. The specimens were heat treated in a $\mathrm{PZ}$ 810 vacuum furnace with heating rate $26.88^{\circ} \mathrm{C} / \mathrm{min}$ and cooling rate $2.15^{\circ} \mathrm{C} / \mathrm{min}$ at $10^{-1}$ to $10^{-2} \mathrm{~Pa}$.

Table 3: Experimental parameters

\begin{tabular}{|c|c|c|}
\hline \multicolumn{3}{|c|}{ Specimen No. 1 } \\
\hline $\begin{array}{c}\text { Brazing } \\
\text { alloy }\end{array}$ & $\begin{array}{c}\text { Brazing } \\
\text { temperature } \\
{\left[{ }^{\circ} \mathrm{C}\right]}\end{array}$ & $\begin{array}{c}\text { Brazing } \\
\text { time } \\
{[\text { min. }]}\end{array}$ \\
\hline NI 102-01 & 1200 & 10 \\
\hline NI 102-02 & 1200 & 10 \\
\hline \multicolumn{3}{|c|}{ Specimen No. 2 } \\
\hline $\begin{array}{c}\text { Brazing } \\
\text { alloy }\end{array}$ & $\begin{array}{c}\text { Brazing } \\
\text { temperature } \\
{\left[{ }^{\circ} \mathrm{C}\right]}\end{array}$ & $\begin{array}{c}\text { Brazing } \\
\text { time } \\
{[\text { min. }]}\end{array}$ \\
\hline NI 102-01 & 1050 & 30 \\
\hline NI 102-02 & 1050 & 30 \\
\hline \multicolumn{3}{|c|}{ Specimen No. 3} \\
\hline Brazing & Brazing & Brazing \\
alloy & temperature & $\begin{array}{c}\left.{ }^{\circ} \mathrm{C}\right] \\
{[\text { mime }}\end{array}$ \\
\hline NI 102-01 & 1100 & 120 \\
\hline NI 102-02 & 1050 & 120 \\
\hline
\end{tabular}

The finished specimens were divided using a cutting disc, and after marking they were sealed with bakelite on a Buehler SimpliMet 1000 device. Then they were ground with grinding paper with 240, 600 and 1200 grit and polished with diamond pastes with 9, 6 and $3 \mu \mathrm{m}$ grit on a semi-automatic Buehler Beta machine. Finally, the specimens were polished using colloidal silica $2 \mu \mathrm{m}$ (Mastermet). To make the structure visible, an etching agent was used $(10 \mathrm{ml}$ $\mathrm{H}_{2} \mathrm{SO}_{4}, 10 \mathrm{ml} \mathrm{HNO}_{3}, 20 \mathrm{ml} \mathrm{HF}$, and $50 \mathrm{ml} \mathrm{H}_{2} \mathrm{O}$ ). The etching time was about 20 seconds. Specimens prepared in this way could be scanned and analyzed by a Neophot 30 light microscope. When measuring the diffusion zones, 11 vertical parallel lines were marked out in each picture, and on each of them points defining the boundaries of the given zone were drawn in. The resulting values are the arithmetic mean of the 11 measurements. Line profiling and element distribution mapping were measured using an ARL SEMQ device.

\section{Results}

\subsection{An evaluation of the wetting of the brazing alloys}

First of all, the wetting was measured on the specimens. Angle $\alpha$ was determined on the pictures created by the light microscope, using graphics software.

An example of these measurements is shown in Fig. 1, 2 and 3, where the changes in this angle as a result of different parameters can also be recognized. The results of the measurements are summarized in Tab. 4.

Tangent to the surface of PM $-\sigma_{S L}$

Tangent to the surface of the brazing alloy $-\sigma_{L V}$

Wetting angle $-\alpha$

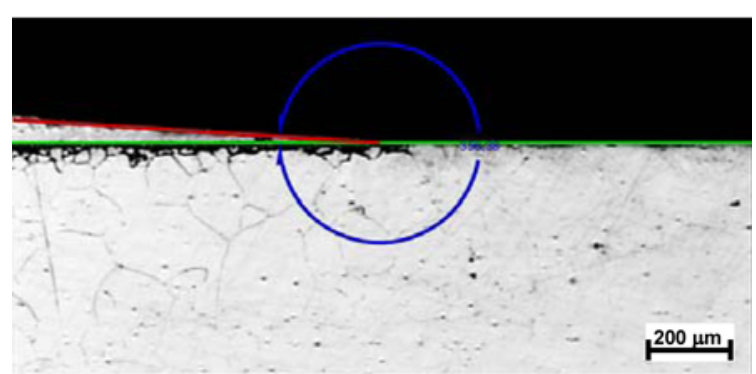

Fig. 1: NI $102-02, \alpha \sim 3.62^{\circ}\left(1200^{\circ} \mathrm{C} / 10 \mathrm{~min}.\right)$

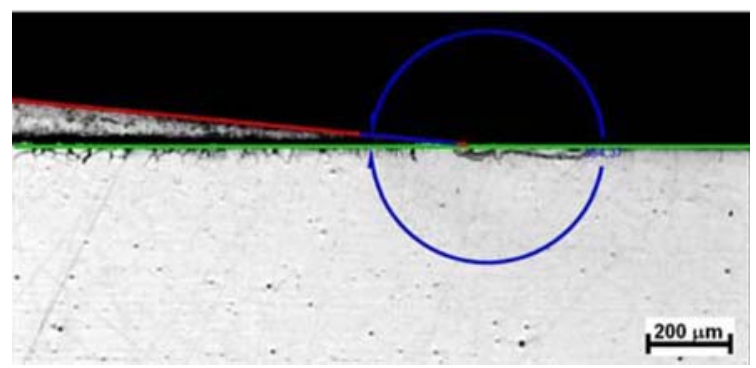

Fig. 2: NI $102-02, \alpha \sim 5.63^{\circ}\left(1050{ }^{\circ} \mathrm{C} / 30 \mathrm{~min}.\right)$

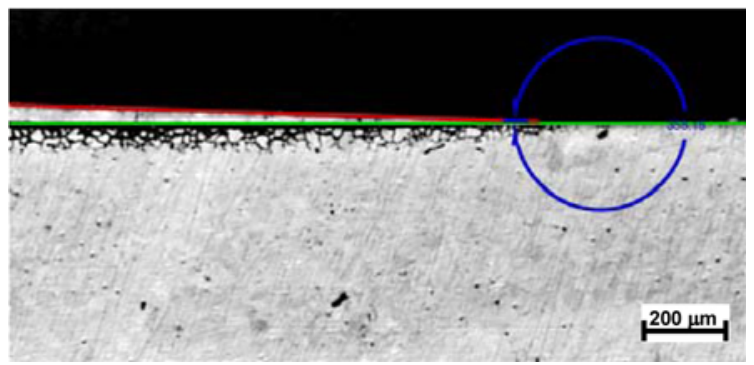

Fig. 3: NI $102-02, \alpha \sim 1.82^{\circ}\left(1050^{\circ} \mathrm{C} / 120 \mathrm{~min}.\right)$ 
Table 4: Values of the wetting angles of the examined brazing alloys at the given parameters

\begin{tabular}{|c|c|c|c|}
\hline $\begin{array}{c}\text { Brazing } \\
\text { alloy }\end{array}$ & $\begin{array}{c}\text { Holding } \\
\text { time at } \\
\text { brazing } \\
\text { temperature } \\
{[\mathrm{min}]}\end{array}$ & $\begin{array}{c}\text { Brazing } \\
\text { temperature } \\
{\left[{ }^{\circ} \mathrm{C}\right]}\end{array}$ & $\begin{array}{c}\text { Contact } \\
\text { angle of } \\
\text { wetting } \\
{\left[{ }^{\circ}\right]}\end{array}$ \\
\hline NI 102-01 & 10 & 1200 & $1.54 \pm 0.5$ \\
\hline NI 102-02 & 10 & 1200 & $2.34 \pm 0.5$ \\
\hline NI 102-01 & 30 & 1050 & $3.40 \pm 0.5$ \\
\hline NI 102-02 & 30 & 1050 & $5.14 \pm 0.5$ \\
\hline NI 102-01 & 120 & 1100 & $1.45 \pm 0.5$ \\
\hline NI 102-02 & 120 & 1050 & $1.50 \pm 0.5$ \\
\hline
\end{tabular}

\subsection{Chemical microanalysis}

A global chemical microanalysis was then performed on the specimens. The objective was to determine the proportion of the basic components of the examined materials in the mutual diffusion and creation of the connection.

The same diffusion reactions took place for all parameters, but they are most visible at brazing temperature $1100^{\circ} \mathrm{C}$ and $120 \mathrm{~min}$. holding time at this temperature - Fig. 4 and Fig. 5.

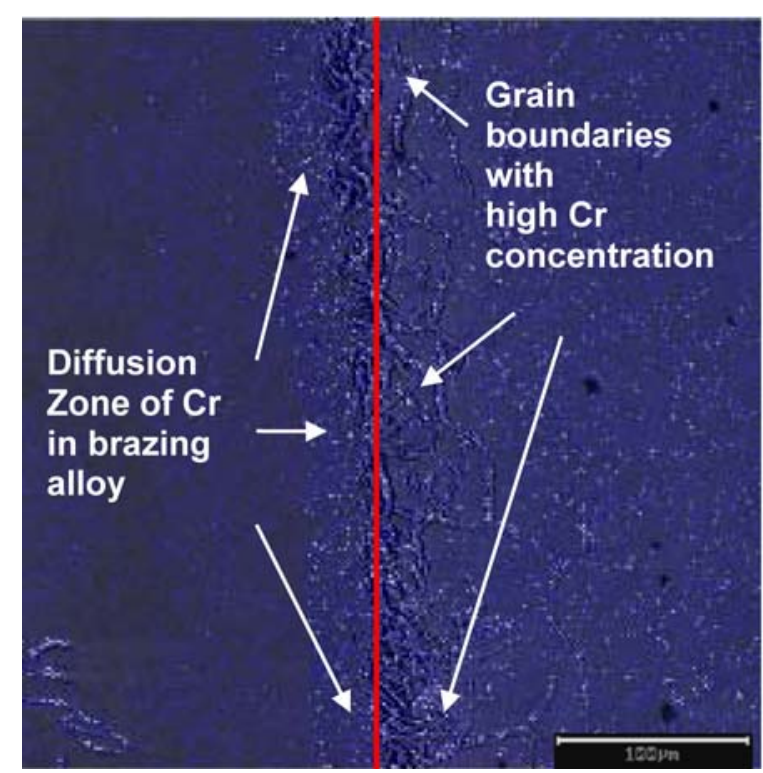

Fig. 4: Cr concentration in transitional area NI $102-$ AISI 321

The zone of Cr diffusion from PM into the brazing alloy can be observed (white points left from the interface) in Fig. 4, where the interface is indicated. Places with the highest $\mathrm{Cr}$ content are white. Cr also diffuses along the grain boundaries from the brazing alloy into PM (visible grain boundaries right from the interface). This is probably caused by B. Cr with $\mathrm{B}$ creates $\mathrm{CrB}_{2}$ borides, and $\mathrm{B}$ diffuses very quickly from the brazing alloy into PM along the grain boundaries.

Fig. 5 shows the concentration of Fe in PM and in the transitional area. The zone of Fe diffusion from $\mathrm{PM}$ into the brazing alloy, similarly as $\mathrm{Cr}$, can be observed. However, the dark areas along the grain boundaries of PM indicate that the concentration of Fe in these places is significantly reduced, and this is also confirmed by linear microanalysis, see Fig. 6 .

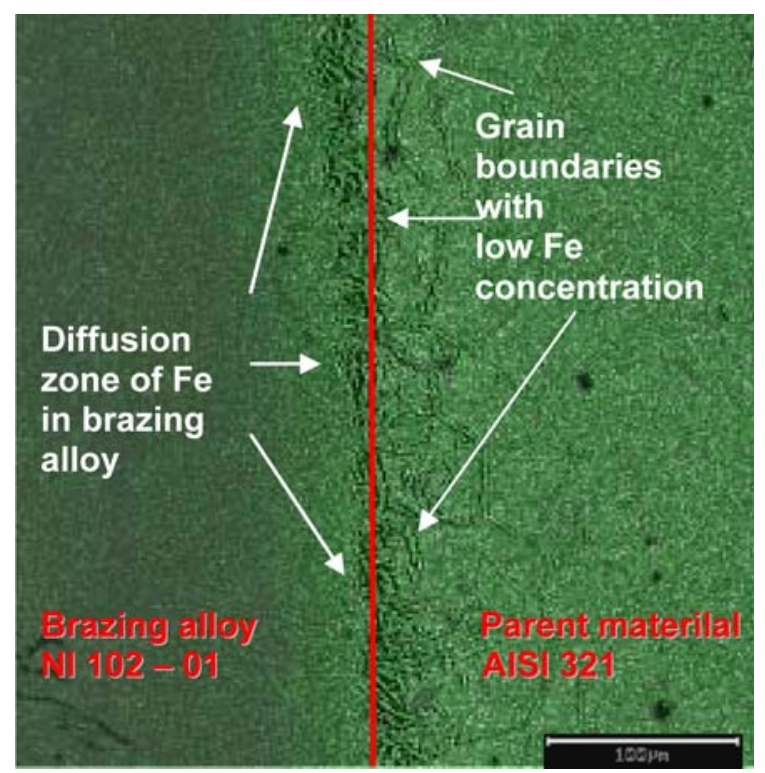

Fig. 5: Fe concentration in transitional area NI $102-$ AISI 321

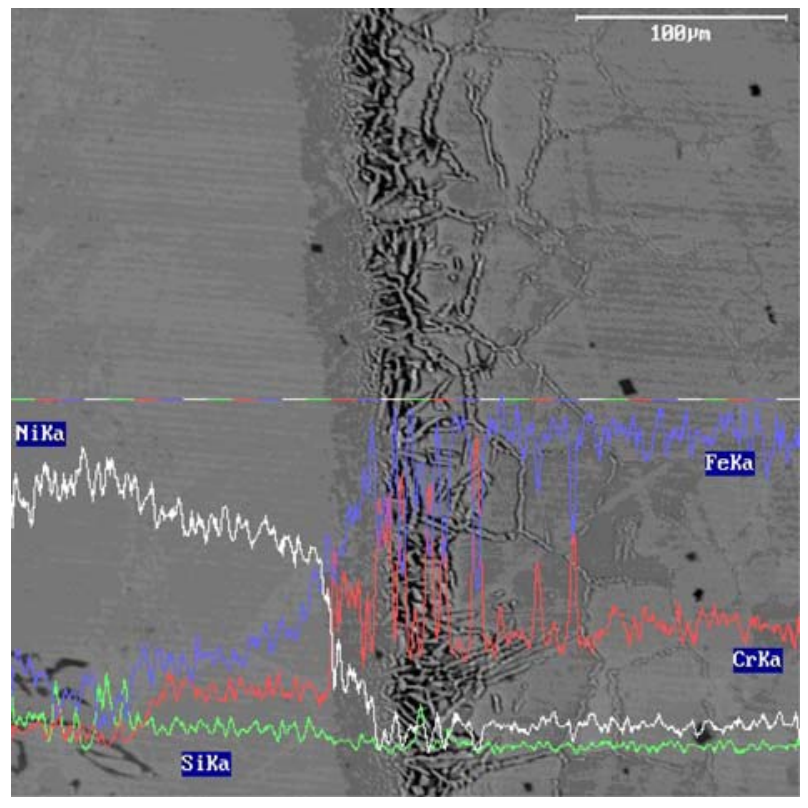

Fig. 6: Linear microanalysis of transitional area NI 10201 - AISI $321\left(1100^{\circ} \mathrm{C} / 120 \mathrm{~min}\right.$.) 
The map of elements $\mathrm{Ni}$ and $\mathrm{Si}$ shows no higher participation in the creation of the brazed connection at any parameters.

\subsection{Measurements of the diffusion zones}

The pictures from the light microscope show the separate diffusion zones in the interface between brazing alloy and PM, see Fig. 7. Specifically the PM solubility zone in the brazing alloy, the diffusion zone of the brazing alloy in PM, the diffusion on the boundaries of the grains, and the zone with a visible change in the microstructure. By measuring these zones for various parameters, it was possible to assess their dependence on the parameters The measurement results are shown in Tab. 5.

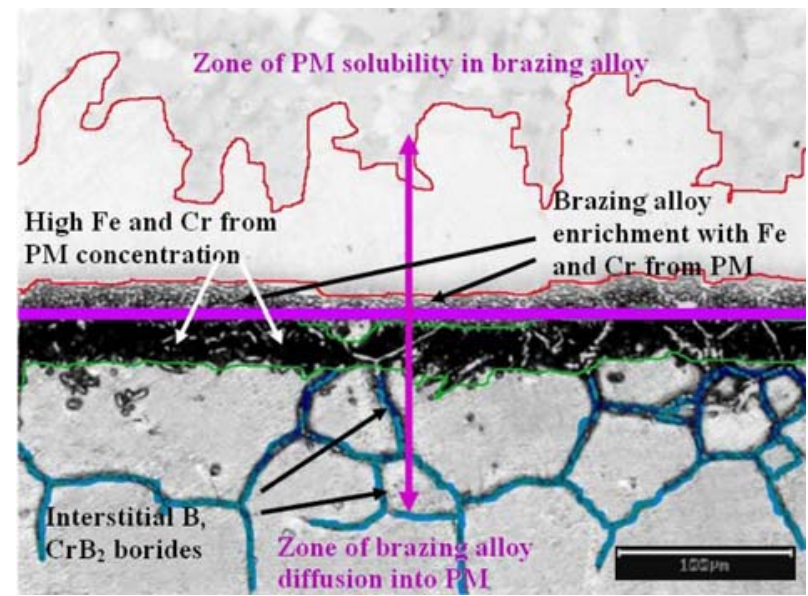

Fig. 7: Diffusion zones in the interface NI 102 - AISI 321

The figures show examples of pictures from the light microscope on which the specific zones were measured. Fig. 8 shows that the solubility zone of $\mathrm{PM}$ and the diffusion zone of the brazing alloy into PM cannot be distinguished with the given param- eters. They were therefore measured as one whole. Fig. 9 shows that these zones are clearly distinguishable after the parameters have been changed.

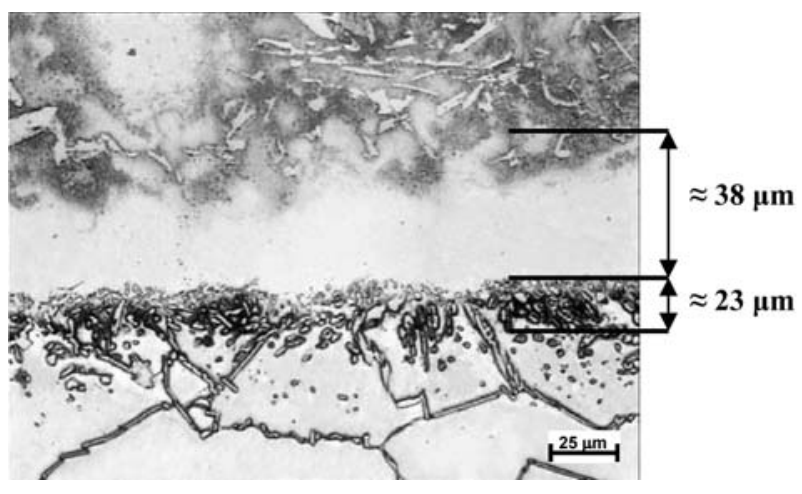

Fig. 8: Interface of NI 102-01 and AISI 321 $\left(1200{ }^{\circ} \mathrm{C} / 10 \mathrm{~min}\right.$.)

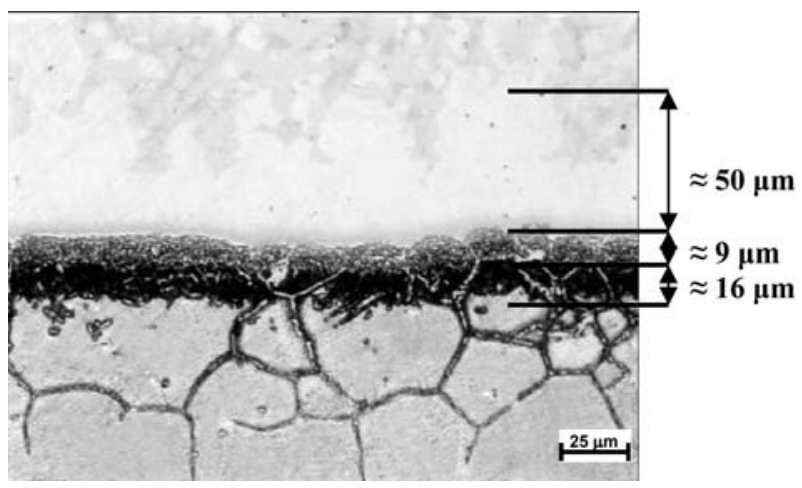

Fig. 9: Interface of NI 102-01 and AISI 321 $\left(1050{ }^{\circ} \mathrm{C} / 30 \mathrm{~min}\right.$.)

With longer holding time at brazing temperature, the PM solubility zone and the diffusion zone of the brazing alloy in PM can be clearly distinguished, even when the brazing temperature is $100{ }^{\circ} \mathrm{C}$ lower, and a significant growth in the width of specific zones can also be seen - Fig. 10 .

Table 5: Recorded dimensions of diffusion zones with various parameters

\begin{tabular}{|c|c|c|c|c|c|c|}
\hline $\begin{array}{c}\text { Brazing } \\
\text { alloy }\end{array}$ & $\begin{array}{c}\text { Holding time } \\
\text { at brazing } \\
\text { temperature } \\
{[\mathrm{min}]}\end{array}$ & $\begin{array}{c}\text { Brazing } \\
\text { temperature } \\
{\left[{ }^{\circ} \mathrm{C}\right]}\end{array}$ & $\begin{array}{c}\text { Zone of PM } \\
\text { solubility } \\
{[\mu \mathrm{m}]}\end{array}$ & $\begin{array}{c}\text { Zone of } \\
\text { diffusion } \\
\text { into PM } \\
{[\mu \mathrm{m}]}\end{array}$ & $\begin{array}{c}\text { Diffusion } \\
\text { along grain } \\
\text { boundaries } \\
{[\mu \mathrm{m}]}\end{array}$ & $\begin{array}{c}\text { Zone of } \\
\text { changed } \\
\text { structure } \\
{[\mu \mathrm{m}]}\end{array}$ \\
\hline NI 102-01 & 10 & 1200 & \multicolumn{2}{|c|}{23} & 93 & 38 \\
\hline NI 102-02 & 10 & 1200 & \multicolumn{2}{|c|}{23} & 109 & 49 \\
\hline NI 102-01 & 30 & 1050 & 9 & 16 & 101 & 50 \\
\hline NI 102-02 & 30 & 1050 & 5 & 18 & 194 & 72 \\
\hline NI 102-01 & 120 & 1100 & 23 & 50 & 203 & 78 \\
\hline NI 102-02 & 120 & 1050 & 13 & 24 & 332 & 132 \\
\hline
\end{tabular}




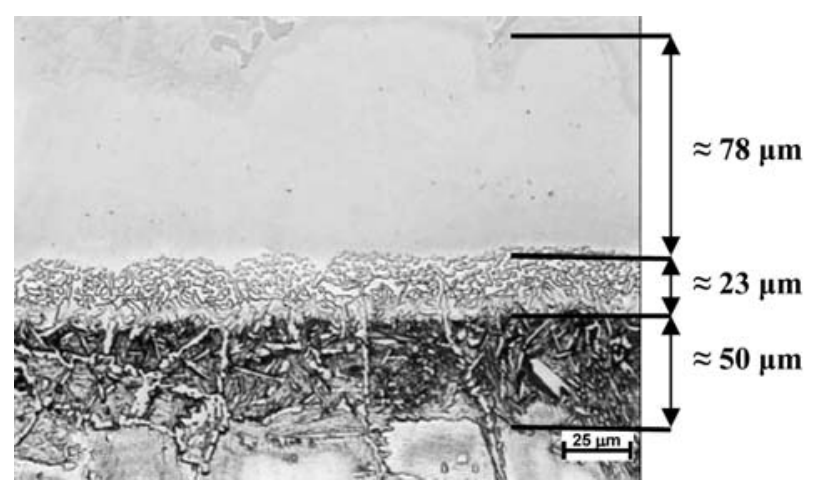

Fig. 10: Interface of NI 102-01 and AISI 321 $\left(1100{ }^{\circ} \mathrm{C} / 120 \mathrm{~min}.\right)$

\section{Discussion}

Brazing alloys NI 102 on stainless steel AISI 321 were distinguished by very good wetting at all brazing parameters. It is known that the angle of wetting decreases with rising temperature and holding time at brazing temperature. However it was found that temperature has a much greater influence on wetting than the holding times at brazing temperature. It was also found that a slightly increased content of B in brazing alloy NI 102-01 in comparison to NI 102-02 caused better wetting of the surface of PM.

A chemical microanalysis showed that the solubility zone of PM in the brazing alloy and also the interface between the brazing alloy and PM are created to a significant extent only by $\mathrm{Fe}$ and $\mathrm{Cr}$, and the results indicate that the proportion of $\mathrm{Ni}$ and $\mathrm{Si}$ is significantly lower. Interstitial atoms of B along the grain boundaries diffuse most quickly into PM, because they are not soluble in the solid solution of Ni. B creates $\mathrm{CrB}_{2}$ phase with $\mathrm{Cr}$. These areas are characterized by a higher concentration of Cr. The concentration of $\mathrm{Fe}$ in these places is significantly reduced.

By analysing the diffusion zones, it was found that, when there is a short holding time, even at a higher brazing temperature it was not possible to distinguish the solubility zone of PM into the brazing alloy from the diffusion zone of the brazing alloy into PM. For the same brazing parameters, brazing alloy NI 102-02 achieved deeper diffusion of the brazing alloy into PM, whereas better penetration of PM into the brazing alloy occurred with brazing alloy NI 10201. The influence of brazing temperature on diffusion depth appeared to be approximately the same as the influence of the holding time at brazing temperature. Even a slight change in the brazing temperature has a big influence on diffusion of the brazing alloy into PM.

\section{Conclusion}

From the measured values of wetting shown in Tab. 4, it can be stated that:

- The wetting of both brazing alloys, NI 102-01 and NI 102-02, is excellent, or even perfect, for all parameters.

- Although the two brazing alloys fall under code NI 102 according to their chemical composition, they have different wetting values.

- The better wetting of brazing alloy NI 102-01 is probably due to a higher content of B.

- The angle of wetting becomes smaller with rising brazing temperature and longer holding time at this temperature. The proportion is therefore inverse.

- According to the measured values, the influence of the brazing temperature on the wetting is more distinct than the effect of the holding time at brazing temperature.

As a result of the chemical microanalysis of the specimens:

- The zone of solubility of PM in the brazing alloy and the interface between the brazing alloy and $\mathrm{PM}$ are created to a significant extent only by $\mathrm{Fe}$ and $\mathrm{Cr}$. The results show that the proportion of $\mathrm{Ni}$ and $\mathrm{Si}$ is significantly lower.

- Interstitial atoms of B along the grain boundaries diffuse most quickly into PM, because they are not soluble in the solid solution of $\mathrm{Ni}$, where they form a phase with $\mathrm{Cr}$. These areas are characterized by a higher concentration of $\mathrm{Cr}$. The concentration of $\mathrm{Fe}$ in these places is significantly reduced.

On the basis of the measured diffusion zone values shown in Tab. 5, the following conclusions can be drawn:

- With a holding time of 10 minutes at brazing temperature $1200^{\circ} \mathrm{C}$, it was not possible to distinguish the solubility zone of PM into the brazing alloy from the diffusion zone of the brazing alloy into PM on the interface of either of the alloys.

- Using the same brazing parameters, brazing alloy NI 102-02 achieved deeper diffusion of the brazing alloy into PM and, conversely, there was better penetration of PM into the brazing alloy in the case of brazing alloy NI 10-01.

- The influence of brazing temperature on diffusion depth is directly proportional to the influence of the holding time at brazing temperature.

- A change or drop in brazing temperature, even a relatively small change $\left(50^{\circ} \mathrm{C}\right)$, has a great influence on the diffusion of the brazing alloy into PM. 


\section{Acknowledgement}

This paper was prepared with support from the VEGA 1/0381/08 project - Research of the influence of physical metallurgical aspects of hightemperature brazing on the structure of connections of metal and ceramic materials and from the APVT 20-010804 project - Development of lead free soft active solder and research of material solderability of metal and ceramic materials with the use of ultrasonic activation.

\section{References}

[1] Available on: http://www.pva-lwt-gmbh.de/ englisch/sites/te_vakuum_verfah.php
[2] Ruža, V., Koleňák, R., Jasenák, J.: Spájkovanie vo vákuu. Trnava, SZS, 2005.

[3] Available on: http://www.aws.org/ w/a/wj/2004/10/030/index.html

[4] Available on: http://cdsweb.cern.ch/record $/ 1151308 ?$ ln=sk

[5] Ruža, V., Koleňák, R.: Spájkovanie materiálov. Bratislava, STU, 2007.

Ing. Robert Augustin doc. Ing. Roman Koleňák, PhD.

Phone: +421949358 111

Faculty of Materials Science and Technology in Trnava

Pavilon T

Bottova 23, 91724 Trnava, Slovak Republic 